\title{
Positional release techniques as a diagnostic-therapeutic approach in physiotherapy
}

\section{Luca Collebrusco}

ASL (Community Health Centre), Gualdo Tadino, Italy; tdr.colle@tiscali.it

Received 29 November 2013; revised 4 January 2014; accepted 15 January 2014

Copyright (C) 2014 Luca Collebrusco. This is an open access article distributed under the Creative Commons Attribution License, which permits unrestricted use, distribution, and reproduction in any medium, provided the original work is properly cited. In accordance of the Creative Commons Attribution License all Copyrights (c) 2014 are reserved for SCIRP and the owner of the intellectual property Luca Collebrusco. All Copyright (C) 2014 are guarded by law and by SCIRP as a guardian.

\section{ABSTRACT}

Manual Therapy is a rehabilitative approach based on the use of therapeutic procedures that includes several techniques, but this paper focuses on what is known as Positional Release (PR), a therapeutic model that includes a series of manoeuvres that are mainly used for the treatment of soft tissue. A deeper understanding of this type of therapeutic approach, especially its well known and widespread variant, StrainCounterstrain, could, through controlled trials and systematic reviews, confirm its effectiveness, definitively explain the neurophysiological mechanism, and therefore make Positional Release another indispensable option in the professional expertise of the physiotherapist.

\section{KEYWORDS}

\section{Manual Therapy; Positional Release; Soft Tissue;} Direct and Indirect Techniques

Manual Therapy is a rehabilitative approach based on the use of therapeutic procedures that, according to the practice of evidence-based medicine, are constantly being updated, and have become an integral part of the specialized training of the physiotherapist.

This type of therapy includes several techniques, but this paper focuses on what is known as Positional Release (PR), a therapeutic model that includes a series of manoeuvres that are mainly used for the treatment of soft tissue, essentially based on the palpation of tissues involved during positioning, so that these reach the highest degree of comfort or ease, without using pain as a guide [1].

In the implementation of the PR model, osteopathic medicine has played a key role [2] in making three main techniques available: Strain-Counterstrain (SC), Facilitated Positional Release (FPR) and Technical and Functional (TF) are known as "indirect" techniques. High velocity/low amplitude technique (HVLA), Muscular energy technique (ME), and Myofascial Release (MR), are known as "direct" techniques (Figure 1).

In general, the former have the purpose of facilitating the modification of the restriction of mobility, going in the opposite direction to that restriction, by moving the segment affected by the restriction of mobility, to bring it towards a condition of comfort or neutral dynamic; on the other hand, the latter face such restrictions by moving the segment towards the same restriction. Table 1 summarizes the main characteristics of the two groups of techniques.

In daily practice it can be increasingly observed that "indirect" techniques are used, as in conditions of severe pain, recent trauma, post-surgery, severe osteoporosis, or as preparation for more specific and defined (e.g. "direct”) manoeuvres for dysfunctional tissue.

In this regard, physiotherapy provides methods and concepts such as the Mc Kenzie or Mulligan techniques, supported by sufficient evidence of effectiveness. In contrast, the mechanisms that make the PR treatment model a valid therapeutic proposal are not yet entirely clear, as the studies reported in the literature remain rather limited. The use of this model begins, however, with the concept that in hypertonia or contraction it does not tend to reinforce the stretching, but attempts to find ways to provide opportunities for change to the tissue moving away from the restriction of mobility, namely holding or supporting hypertonic tissues and/or contractions in an analgesic and shortening position, and thus induce a spontaneous change.

According to some authors, the maintenance of tissues in a state of comfort during treatment PR creates improved circulation, resulting in a reduction of ischemia 

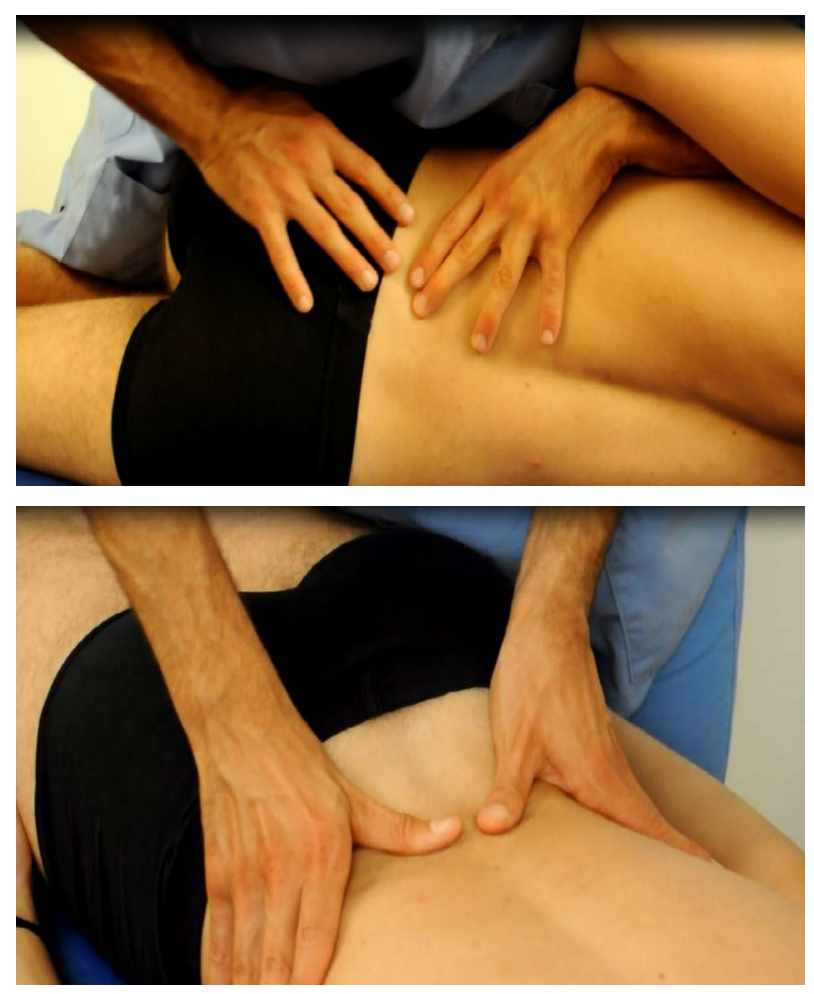

Figure 1. HVLA and soft tissue techniques.

Table 1. The main characteristics of the two groups of techniques.

\begin{tabular}{|c|c|}
\hline $\begin{array}{l}\text { "Direct" techniques } \\
\text { HVLA-ME-MR }\end{array}$ & $\begin{array}{l}\text { "Indirect" techniques } \\
\text { SC-FPR-TF }\end{array}$ \\
\hline $\begin{array}{l}\text { - directed against the } \\
\text { restrictive barrier }\end{array}$ & $\begin{array}{l}\text { - oriented towards a condition } \\
\text { of comfort }\end{array}$ \\
\hline $\begin{array}{l}\text { - defined neurophysiologic } \\
\text { mechanisms }\end{array}$ & $\begin{array}{l}\text { - undefined neurophysiologic } \\
\text { mechanisms }\end{array}$ \\
\hline $\begin{array}{l}\text { - requires the cooperation of } \\
\text { the patient }\end{array}$ & $\begin{array}{l}\text { - does not require patient } \\
\text { cooperation }\end{array}$ \\
\hline $\begin{array}{l}\text { - may be too invasive and } \\
\text { uncomfortable for the patient }\end{array}$ & - always tolerable to the patient \\
\hline
\end{tabular}

[3]. Further studies suggest a dampening effect on the overall level of excitability within the restricted zone of mobility, with a decrease in spinal facilitation [4], while others propose the proprioceptive hypothesis according to which mechanisms come into play with feedback in the CNS, which is the main afferent response of the neuromotor spindles would be modulated by a further spindle function which includes the efferent system range controlled by higher brain centres [5].

The hypotheses cited so far still remain poorly supported at the scientific level, but the widespread use of PR within the osteopathic profession and the presence of similarities with the classic "indirect" methods mentioned above call for a reflection on the importance of its use in the field of physiotherapy. A deeper understanding of this type of therapeutic approach, especially its well known and widespread variant, Strain-Counterstrain, could, through controlled trials and systematic reviews, confirm its effectiveness, definitively explain the neurophysiological mechanism, and therefore make Positional Release another indispensable option in the professional expertise of the physiotherapist.

\section{ACKNOWLEDGEMENTS}

The authors would like to thank Dr Liam Boyle for translating and editing this paper.

\section{REFERENCES}

[1] Chaitow, L. (2007) Positional release techniques. 3rd Edition, Churchill Livingstone, Edinburgh.

[2] Jones, L.H. (1981) Strain and counterstrain. The American Academy of Osteopathy, Indianapolis.

[3] Chaitow, L. (2003) Modern neuromuscular technique. 2nd Edition, Churchill Livingstone, Edinburgh.

[4] D’Ambrogio, K.J. and Roth, G.B. (1997) Positional release therapy: Assessment \& treatment of musculoskeletal dysfunction. Mosby, St. Louis.

[5] Korr, I.M. (1975) Proprioceptors and somatic dysfunction. The Journal of the American Osteopathic Association, 74, 638-650. 